Mini Review

\title{
The 2014 ebola virus outbreak in west africa: current perspectives for prevention and treatment
}

\author{
Volume I Issue 4 - 2014 \\ Jocelyn Yelle \\ Antiviral InteliStrat Inc., Canada
}

\section{Introduction}

In 2014, West Africa has been the scene of the worst Ebola virus outbreak in history, with no end in sight. ${ }^{1-4}$ This health crisis is reportedly associated with an outlier strain of Zaire Ebola virus. ${ }^{4}$ While the first infections were reported in December of last year, the number of cases has literally exploded during the summer months of 2014, affecting mainly Guinea, Liberia and Sierra Leone, with a few cases in Mali, Nigeria and Senegal. According to the World Health Organization (WHO), as many as 13703 people have been infected by the Ebola virus as of October 27, resulting in 4922 fatalities. ${ }^{5}$ The real figures are most likely higher as the healthcare systems in these countries have been overwhelmed by the large number of cases, the limited resources and the lack of basic facilities. While the local Ebola outbreaks in Senegal and Nigeria were declared over in October, the transmission remained persistent and widespread in Guinea, Liberia, and Sierra Leone, especially in the capital cities of these countries. Notably, on a smaller scale, there has also been in 2014 a separate and independent outbreak of Ebola virus in the Democratic Republic of the Congo, which involved 66 cases and resulted in 49 deaths so far, although the situation there seems to remain under relative control. ${ }^{5}$

Ebola virus, a member of the Filoviridae family, was discovered in 1976 as the causative agent of severe hemorrhagic fevers in Sudan and Zaire ${ }^{6-10}$ It was only the second Filovirus identified in humans, after the Marburg virus a few years before. ${ }^{11,12}$ Besides high fever and rapid health deterioration, the Ebola virus disease is characterized mainly by drastic alterations of the immune system due to viral replication in dendritic cells and macrophages, leading to suppression of interferon production along with massive release of inflammatory proteins, and by a weakening of blood vessel walls, resulting in blood leakage, hypotension, and serious haemorrhages. The virus affects directly and indirectly several organs and systems in the body, notably the liver, the adrenal gland and the gastro-intestinal tract. ${ }^{13}$

Despite the rapid evolution of the disease in patients and its high mortality rate that can reach $90 \%$, the sporadic nature of Ebola virus outbreaks and the relatively small number of people affected in Africa over the years have led to the general perception of the virus as a rare pathogen with little impact on human populations. This has also resulted in a lack of interest of developed countries and the pharmaceutical industry towards the disease until recently. Because the virus was perceived primarily as a potential bio weapon in the hands of terrorists, much of the research on Ebola was conducted behind closed doors in military facilities under secrecy, and/or as part of the Bio Shield program in the US. Now, almost 40 years after the first virus detection, not much has been achieved to prevent or treat the infection in the general population.

The global response to the 2014 Ebola crisis has been slow, despite alarming signals from health organizations on the ground such as Médecins Sans Frontières. In March, the WHO issued its first communique on the outbreak and it was only on August 8 that the
Correspondence: Jocelyn Yelle, Antiviral InteliStrat Inc., 3077 Edouard-Montpetit St., Suite 406, Laval (QC), Canada H7T 2K8, Tel 5|4-8|6-8856 Email yellej@videotron.ca

Received: November 01, 2014 | Published: November 15, 2014

organization qualified the situation as a Public Health Emergency of International Concern. Under pressing demands to test experimental vaccines and drugs in infected patients, a WHO expert panel unanimously declared in August that considering the exceptional circumstances faced by the medical community, such measures would be ethical provided specific criteria are met.

As for any viral disease, there are two traditional approaches to control the outbreak and avoid a repeat of the current crisis in the future: prevention through vaccines, and treatment via viral inhibitors. In the current situation, both approaches must be pursued urgently: vaccines are needed for health personal and potentially for local populations and treatment drugs for infected people.

Table 1 lists a series of experimental vaccines, antibodies and inhibitors that are currently under development for Ebola, or have been in recent years. Remarkably, only a few of these agents have reached the first stage of clinical development (Phase I), and this has often been achieved in the context of the current crisis.

\section{Vaccines}

Due to the pathogenicity of the virus, no conventional vaccines consisting of inactivated/killed virus, or made from an attenuated viral strain, are being developed for Ebola because of the risk of incomplete inactivation of the virus or of reversion to a fully active form. Instead, these vaccines are based on relatively new approaches that have been made possible with the advent of molecular biology and recombinant genetic technologies introduced during the last 10-20 years. Since the Ebola virus surface glycoprotein has been identified as a potent immunogen, experimental Ebola vaccines use this protein to elicit an immune response. Remarkably, most of the vaccines use a non-pathogenic virus (Adenovirus, Vesicular Stomatitis Virus [VSV], attenuated Venezuelan Equine Encephalitis virus [VEE]) as an expression vector to produce the Ebola surface glycoprotein. Other vaccines are based on plasmids to express the Ebola surface glycoprotein, which either assemble to form nanoparticles, or are used per se as immunogens with adjuvant. 
Table I Selected preventive and therapeutic agents in development for Ebola*

\begin{tabular}{|c|c|c|c|c|c|}
\hline Sponsor/ Organization & Product name & \multicolumn{2}{|c|}{ Type of product } & \multirow{2}{*}{ Development status } & \multirow{2}{*}{$\begin{array}{l}\text { Remarks } \\
\text { AlphaVax replicon } \\
\text { Vaccine technology, } \\
\text { developed for various } \\
\text { viruses }\end{array}$} \\
\hline AlphaVax Inc. & $\mathrm{ArV}^{\mathrm{TM}}$ vaccine for Ebola & Vaccine & $\begin{array}{l}\text { Viral expression } \\
\text { vector (VEE) }\end{array}$ & & \\
\hline $\begin{array}{l}\text { GlaxoSmithKline } \\
\text { (Okairos) }\end{array}$ & cAd3-ZEBOV & Vaccine & $\begin{array}{l}\text { Viral expression } \\
\text { vector (Adenovirus) }\end{array}$ & $\begin{array}{l}\text { Phase I ongoing (U.S., } \\
\text { U.K. and Mali) }\end{array}$ & $\begin{array}{l}\text { Initially developed by } \\
\text { Okairos, acquired by } \\
\text { GSK in } 2013\end{array}$ \\
\hline $\begin{array}{l}\text { Inovio Pharmaceuticals } \\
\text { Inc. }\end{array}$ & SynCon ${ }^{\circledR}$ Ebola vaccine & Vaccine & $\begin{array}{l}\text { Plasmid expression } \\
\text { vector }\end{array}$ & $\begin{array}{l}\text { Preclinical (Phase I to } \\
\text { start in } \mathrm{HI} 20 \mathrm{I5})\end{array}$ & $\begin{array}{l}\text { DNA vaccine designed } \\
\text { for multiple strains of } \\
\text { Ebola virus }\end{array}$ \\
\hline $\begin{array}{l}\text { Integrated } \\
\text { BioTherapeutics Inc. }\end{array}$ & FiloVax & Vaccine & $\begin{array}{l}\text { Recombinant VLP } \\
\text { protein vaccine }\end{array}$ & Preclinical & $\begin{array}{l}\text { Also developing pan- } \\
\text { Filovirus monoclonal } \\
\text { antibodies }\end{array}$ \\
\hline $\begin{array}{l}\text { Johnson \& Johnson } \\
\text { (Crucell /Bavarian } \\
\text { Nordic) }\end{array}$ & $\begin{array}{l}\text { VRC-EBOADV0I8-00-VP } \\
\text { (Ebola rAd5 vaccine) }\end{array}$ & Vaccine & $\begin{array}{l}\text { Viral expression } \\
\text { vector (Adenovirus) }\end{array}$ & $\begin{array}{l}\text { Preclinical (Phase I to } \\
\text { start in Jan. 20I5) }\end{array}$ & $\begin{array}{l}\text { Similar vaccines designed } \\
\text { for Marburg and bivalent } \\
\text { Ebola/Marburg }\end{array}$ \\
\hline Novavax Inc. & EBOV GP & Vaccine & Nanoparticles & $\begin{array}{l}\text { Preclinical } \\
\text { (Phase I to start in } \\
\text { Dec. 20I4) }\end{array}$ & $\begin{array}{l}\text { Consists in recombinant } \\
\text { viral glycoprotein with } \\
\text { adjuvant }\end{array}$ \\
\hline Profectus Biosciences Inc. & $\begin{array}{l}\text { VesiculoVax Ebola } \\
\text { (Z-EboV/S-EboV /MarV- } \\
\text { rVSVN4CTI) }\end{array}$ & Vaccine & $\begin{array}{l}\text { Viral expression } \\
\text { vector (VSV) }\end{array}$ & Preclinical & $\begin{array}{l}\text { Another vaccine is } \\
\text { designed as trivalent, for } \\
\text { Ebola (Zaire and Sudan } \\
\text { strains) and Marburg } \\
\text { Filoviruses }\end{array}$ \\
\hline $\begin{array}{l}\text { Public Health Agency } \\
\text { of Canada (PHAC) / } \\
\text { NewLink Genetics Inc. }\end{array}$ & $\begin{array}{l}\text { rVSV-ZEBOV-GP (BPSC- } \\
\mathrm{I00I)}\end{array}$ & Vaccine & $\begin{array}{l}\text { Viral expression } \\
\text { vector (VSV) }\end{array}$ & Phase I ongoing & $\begin{array}{l}\text { Donated to WHO in } \\
\text { Aug. } 20 \mathrm{I} 4 \text { to help in } \\
\text { West Africa outbreak; } \\
\text { now developed by } \\
\text { NewLink Genetics Inc. }\end{array}$ \\
\hline $\begin{array}{l}\text { Mapp Biopharmaceutical } \\
\text { Inc. }\end{array}$ & $\begin{array}{l}\text { ZMapp } \\
(M B-003+Z M A b)\end{array}$ & Antibody & $\begin{array}{l}\text { Represents a mix } \\
\text { of } 3 \text { humanized } \\
\text { monoclonal } \\
\text { antibodies produced } \\
\text { in plants (Nicotiana } \\
\text { benthamiana) }\end{array}$ & $\begin{array}{l}\text { Used under Emergency } \\
\text { IND to treat patients }\end{array}$ & $\begin{array}{l}\text { Worldwide license } \\
\text { of ZMAb antibody } \\
\text { portfolio obtained from } \\
\text { Defyrus Inc., pioneered } \\
\text { at the Public Health } \\
\text { Agency of Canada } \\
\text { (PHAC) }\end{array}$ \\
\hline $\begin{array}{l}\text { BioCryst Pharmaceuticals } \\
\text { Inc. }\end{array}$ & BCX-4430 & Inhibitor & $\begin{array}{l}\text { RNA Polymerase } \\
\text { Inhibitor }\end{array}$ & Preclinical & $\begin{array}{l}\text { Broad spectrum activity } \\
\text { (> } 20 \text { RNA viruses) }\end{array}$ \\
\hline Chimerix Inc. & Brincidofovir & Inhibitor & $\begin{array}{l}\text { Mechanism of } \\
\text { action unclear vs } \\
\text { Ebola }\end{array}$ & $\begin{array}{l}\text { Used under Emergency } \\
\text { IND to treat patients } \\
\text { (Phase II in } \\
\text { preparation) }\end{array}$ & $\begin{array}{l}\text { In development for CMV } \\
\text { and other DNA viruses; } \\
\text { in vitro activity vs Ebola } \\
\text { virus }\end{array}$ \\
\hline Sarepta Therapeutics & AVI-7537 & Inhibitor & Antisense & $\begin{array}{l}\text { Phase I } \\
\text { (funding issues) }\end{array}$ & $\begin{array}{l}\text { Similar approach used } \\
\text { for Marburg virus } \\
\text { antisense program (AVI- } \\
7288 \text { ) }\end{array}$ \\
\hline $\begin{array}{l}\text { Tekmira Pharmaceuticals } \\
\text { Inc. }\end{array}$ & TKM-Ebola & Inhibitor & RNAi & $\begin{array}{l}\text { Phase I } \\
\text { FDA-approved for } \\
\text { Emergency IND to } \\
\text { treat patients }\end{array}$ & $\begin{array}{l}\text { Phase I was put on hold } \\
\text { by FDA in Jul. } 2014 \text {, then } \\
\text { allowed to proceed } \\
\text { (partial hold) in the } \\
\text { context of the Ebola } \\
\text { crisis }\end{array}$ \\
\hline $\begin{array}{l}\text { Toyama Chemicals / } \\
\text { Fujifilm Holdings Corp. }\end{array}$ & T-705 (Favipiravir / Avigan) & Inhibitor & $\begin{array}{l}\text { RNA Polymerase } \\
\text { Inhibitor }\end{array}$ & Preclinical & $\begin{array}{l}\text { Currently in clinical } \\
\text { Phase III for Influenza } \\
\text { virus infection }\end{array}$ \\
\hline
\end{tabular}

*Information collected through Antiviral InteliStrat Inc. database and publicly available sources

At least two vaccines against the Ebola virus, both using the viral expression vector approach, are currently in Phase I evaluation in the context of the present crisis, meaning that they are tested for safety and immunogenicity in humans. One of these vaccines (cAd3-ZEBOV) uses an Adenovirus vector and was obtained by GlaxoSmithKline through its acquisition of Okairos in 2013. Another promising 
vaccine, based on a VSV vector, was developed initially by the Public Health Agency of Canada (PHAC) and has been licensed to New Link Genetics Inc. for large scale production and further development. Notably, this vaccine was donated to WHO for use in West Africa in August. These two vaccines currently represent the most advanced options in terms of prevention of Ebola virus infection. Unfortunately, their efficacy against the viral infection in humans has yet to be established, despite excellent results in animal studies.

\section{Therapeutic agents}

Interestingly, besides AVI-7537 (antisense molecule) and TKMEbola (RNAi) which are specifically designed to inhibit Ebola replication, all other agents represent broadly active compounds that display antiviral activity against many types of RNA viruses, including Filoviruses. TKM-Ebola represents a cocktail of siRNA molecules targeting the $\mathrm{L}$ polymerase enzyme, along with viral proteins 24 and 35 of Ebola virus (Zaire strain). BCX-4430 acts as a broad spectrum RNA polymerase inhibitor with activity against over 20 RNA viruses in various families. The other RNA polymerase inhibitor, T-705 (Favipiravir), is currently developed for Influenza virus infections, but has significant activity against other viruses as well, including the Ebola virus. ${ }^{14}$ This particular compound has been used in several clinical trials involving hundreds of patients, so its safety profile is well known. Toyama Chemicals/Fujifilm has recently announced its intention to make the product available for evaluation in Ebola-infected patients by mid-November. That timing could potentially have a positive impact for Ebola-infected patients, as the manufacturing process for large scale production of T-705 is already in place. Brincidofovir represents a special case. The compound, a phosphonate derivative of Cidofovir, is being developed mainly for Cytomegalovirus but has significant activity against other DNA viruses. It has also shown in vitro activity against the Ebola virus, an RNA virus, so its precise mechanism of action for this particular virus is unclear. Chimerix announced on Oct. 29 plans for a Phase II study of the compound, which has been administered under compassionate use to two US patients infected with Ebola.

Another interesting case is ZMapp, a cocktail of three humanized monoclonal antibodies produced in tobacco plants by Mapp Biopharmaceutical Inc. The antibodies were initially developed by Defyrus Inc. and PHAC in Canada, before licensing to Mapp. ZMapp showed significant efficacy in studies done with Ebola-infected nonhuman primates. ${ }^{15-17}$ It was also administered under compassionate use to 7 patients infected with Ebola so far. At this point, the production process in plants is not optimized and cannot generate the amount of product needed for treating a large number of patients so other manufacturing approaches are being explored.

\section{Conclusion}

There are definitely some promising vaccines and therapeutic agents in the pipeline to fight Ebola virus infections. However, time is running out for thousands of patients infected with Ebola and other people at risk of infection in West Africa. By the time safe and effective vaccines and therapies become available, it will be too late for many (most?) of the currently affected populations.

Another important aspect of the Ebola crisis is often neglected: besides drugs and vaccines, what is mostly needed in affected countries is human personal at the front line, physicians, nurses and other people, ready to care for the patients and administer whatever treatments are available.
Again, we were not ready for such a large-scale crisis. This has been a crucial test of our ability to face rapidly evolving viral outbreaks and the results underline several weaknesses in our way to address global viral threats: lack of flexibility of our large health organizations, inadequate infrastructures and insufficient personal on the front line, mutual lack of trust between health personal and local populations, absence of a clear and consistent message to avoid fear and panic in the general population, inability of our organizations to sense and evaluate the situation on the ground, to adjust and coordinate an efficient response to the crisis.

Let's hope we learn from our mistakes and get ready for the next viral outbreak.

\section{Acknowledgments}

None.

\section{Conflicts of interest}

The author is President of Antiviral InteliStrat Inc. He declares having no financial links or interests in the other organizations listed in the manuscript.

\section{References}

1. Baize S, Pannetier D, Oestereich L et al. Emergence of Zaire Ebola Virus Disease in Guinea - Preliminary Report. $N$ Engl J Med. 2014;371(15):1418-1425.

2. Briand S, Bertherat E, Cox P, Formenty P et al. The international Ebola emergency. N Engl J Med. 2014;371(13):1180-1183.

3. Chan M Ebola virus disease in West Africa-no early end to the outbreak. N Engl J Med. 2014;371(13):1183-1185.

4. Gatherer D The 2014 Ebola virus disease outbreak in West Africa. J Gen Virol. 2014;95(Pt 8):1619-1624.

5. World Health Organization Ebola Response Roadmap Situation Report. 2014

6. Seah SK Lassa, Marburg and Ebola: newly described African fevers Can Med Assoc J 1978;118(4):347-348, 350.

7. Pattyn S, van der Groen G, Courteille G et al. Isolation of Marburglike virus from a case of haemorrhagic fever in Zaire. Lancet. 1977;1(8011):573-574.

8. Bowen ET, Lloyd G, Harris WJ et al. Viral haemorrhagic fever in southern Sudan and northern Zaire. Preliminary studies on the aetiological agent. Lancet. 1977;1(8011):571-573.

9. World Health Organization Ebola haemorrhagic fever in Sudan, 1976. Report of a WHO/International Study Team. Bull World Health Organ. 1978;56(2):247-270.

10. World Health Organization Ebola haemorrhagic fever in Zaire, 1976. Bull World Health Organ 1978;56(2):271-293.

11. Luby JP, Sanders CV Green monkey disease ("Marburg virus" disease): a new zoonosis. Ann Intern Med. 1969;71(3):657-660.

12. Martini GA Marburg agent disease: in man. Trans $R$ Soc Trop Med Hyg 1969;63(3):295-302.

13. Ansari AA Clinical features and pathobiology of Ebolavirus infection. $J$ Autoimmun pii: 2014;S0896-8411(14):00130-00139.

14. Oestereich L, Ludtke A, Wurr S et al. Successful treatment of advanced Ebola virus infection with T-705 (favipiravir) in a small animal model. Antiviral Res. 2014;105:17-21. 
15. Olinger GG Jr, Pettitt J, Kim D et al. Delayed treatment of Ebola virus infection with plant-derived monoclonal antibodies provides protection in rhesus macaques. Proc Natl Acad Sci USA 2012;109(44):18030-18035.

16. Qiu X, Wong G, Fernando L et al. mAbs and Ad-vectored IFN-0 therapy rescue Ebola-infected nonhuman primates when administered after the detection of viremia and symptoms. Sci Transl Med 2013;5(207):207ra143.
17. Qiu X, Wong G, Audet J et al. Reversion of advanced Ebola virus disease in nonhuman primates with ZMapp. Nature. 2014;514(7520):47-53. 